\title{
Structural changes in an estuarine subtidal epibenthic community: biotic and physical causes
}

\author{
Solange Brault and Edwin Bourget
}

Departement de biologie, Universite Laval, Sainte-Foy, Quebec G1K 7P4, Canada

\begin{abstract}
The development of an epibenthic community in the St. Lawrence Estuary (Quebec Canada) was studied using artificial substrata. Community development was followed on series of panels immersed for periods ranging from 1 to $18 \mathrm{mo}$. Colonization and decolonization rates of algal and animal species were higher during summer than during winter. Intensity of settlement varied from year to year for a given species. In the long series $(18 \mathrm{mo}), 2$ early colonizers, the barnacle Balanus crenatus and the colonial hydroid Obelia longissima, dominated the community and determined much of its physical structure during most of the study period. Biogenic heterogeneity created by the dominant species was shown to increase the number of both individuals and new species. The mechanisms responsible for this attraction (increase in surface area, new types of substrata, creation of crevices, modification of water movements) are discussed. Subsequent disruption of the structure, due to high mortality of the 2 dominants, caused impoverishment of the assemblage. It is suggested that $B$. crenatus and $O$. longissima maintain their dominance using 3 strategies: (1) dense and early colonization and/or rapid growth; (2) greater attractiveness for other species than a flat substratum, which will eventually also cause the elimination of other species (epibionts) on the panels at the time of their own disappearance; (3) positive or neutral attractiveness to settling larvae of their own species, ensuring their rapid recolonization and maintenance of stable populations.
\end{abstract}

\section{INTRODUCTION}

Causes and mechanisms explaining the complexity of natural communities have been major subjects of study in ecology. The initial concept of successione.g. development being an orderly and directional process leading to a climax (Clements, 1916; Odum, 1969) - has served as a framework for many studies of communities. However, numerous studies contradict this view, and alternative ideas and models have been proposed (Drury and Nisbet, 1973; Connell and Slatyer, 1977; Grime, 1977).

Rather than referring to the general properties of the communities, some authors have stressed the importance of the responses of individual species to abiotic or biotic events to account for successional changes. In many recent studies, the role of the dominant species has consequently been highlighted, since by definition they often determine much of the structure of the community (Dayton, 1975). In the marine benthic environment, dominant species have been studied in terms of resistance to physical perturbations (Dean, 1977; Sousa, 1979, 1980; Sutherland, 1981), competitive interactions (Jackson, 1977; Sutherland and Karlson,
1977; Sutherland, 1978; Karlson and Cariolou, 1982), predation (Paine, 1974, 1980; Menge, 1976; Brock, 1979), and in terms of influence of biogenic structure on other species (Dean, 1977; Vance, 1978; Woodin, 1978; Brock, 1979; Russ, 1980). However, non-dominant species have also been observed to account for much of the structure of certain communities (keystone species: Paine, 1974, 1980)

In the present paper, we report on the development of a subtidal fouling community as studied on artificial substrata. Patterns of development are described, the seasonality of the changes examined, and the effects of dominant species on presence and abundance of other species are investigated

\section{STUDY AREA}

The study site was at McCormick Cove, on the north shore of the Lower St. Lawrence Estuary, about $20 \mathrm{~km}$ east of Baie-Comeau (Fig. 1). This cove, oriented north to south, is protected from most heavy winds and storms. Because of this particular orientation and the general surface circulation in the Estuary (El-Sahb, 


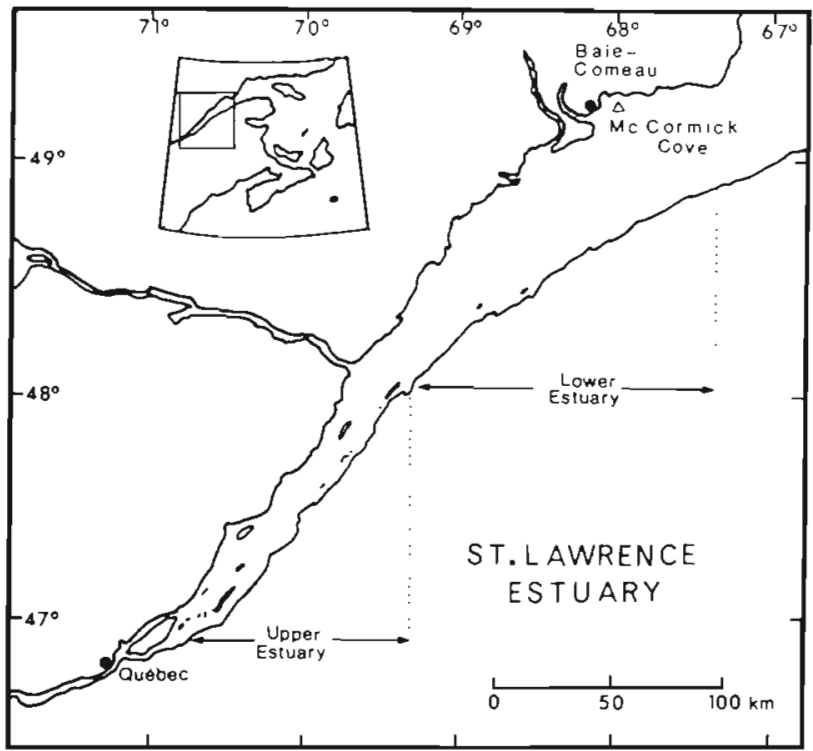

Fig. 1. Map of St. Lawrence Estuary (Quebec, Canada) showing sampling site at McCormick Cove

1976), ice covers the study site only intermittently from December to March. The sampling site was located on a slightly sloping boulder field, at $5 \mathrm{~m}$ depth.

Tidal range is $4 \mathrm{~m}$ during spring tides; it has a mean of $2.6 \mathrm{~m}$. Water temperature ranges from $-1{ }^{\circ} \mathrm{C}$ in January to $12.5^{\circ} \mathrm{C}$ in August. Salinity varies from $25.5 \%$ to $31.5 \%$, and is slightly higher in winter than in summer.

\section{MATERIAL AND METHODS}

Field work was carried out from June 1978 to January 1980. Arborite panels $(10 \times 20 \mathrm{~cm})$ were attached vertically to 2 iron frames. The frames maintained the panels at about $40 \mathrm{~cm}$ above the bottom. The panels were immersed on 3 different dates: 7 June 1978, 10 November 1978 and 9 May 1979. Series of 3 replicate panels were retrieved at monthly intervals (except when otherwise indicated).

Using SCUBA, the panels collected were individually placed in plastic bags underwater. Samples were preserved in $4 \%$ formaldehyde in seawater until analysed.

In the laboratory, the center $10 \times 15 \mathrm{~cm}$ area on both sides of each panel, as well as the liquid contained in the bags, were examined under a dissecting microscope. Organisms were identified to species or genus level (except some rare individuals) and counted Attachment site (bare substratum, barnacles, or colonial hydroids) was noted for each sessile individual. The density of epibionts on barnacles and on the bare substratum was then calculated using the proportion of the panel area occupied by each type of substrata i.e. number of epibionts X ( $\%$ cover $150 \mathrm{~cm}^{-2}$ ). The density of organisms on hydroids was calculated as number of epibionts $150 \mathrm{~cm}^{-2}$, since most of them were found on the upright branches of the hydroids.

Percent cover of all sessile species, except hydrozoans, was evaluated using a random dot technique. One hundred computer-generated random points were placed on $10 \times 15 \mathrm{~cm}$ transparent plastic surfaces. Three different plastic sheets were successively placed on each panel side, and points falling on an organism were counted by species.

Because hydroids propagate vegetatively by means of very slender stolons $(0.2$ to $0.5 \mathrm{~mm}$ diameter) that spread over the entire surface, the point technique overestimated their cover. Thus an alternative technique was used. A grid of $10 \times 10$ contiguous squares was placed in the ocular of the microscope and a number of microscope fields chosen by random coordinates were examined on the panels. Since each square was approximately of the same dimension as the diameter of a stolon, the number of squares in the grid filled by stolons was counted, and treated as percent cover. The number of samples (n) required to reach a $85 \%$ precision on the mean was determined as:

$$
\mathrm{n}=\frac{\mathrm{s}^{2}}{\mathrm{D}^{2} \overline{\mathrm{x}}^{2}}
$$

where $\mathrm{D}=$ index of precision; $\mathrm{s}=$ standard deviation; $\overline{\mathrm{x}}=$ arithmetic mean (Elliott, 1971).

The abundance and percent cover data used in this study often had a multimodal frequency distribution and therefore could not be normalized. Nevertheless, we used the normal parameters (mean, standard deviation) when giving values for these variables. However, whenever a statistical test was required, non-parametric methods were used.

There were no significant differences in the number of species, abundance and percent cover of the common species between the 2 sides of each panel, using a Kruskal-Wallis 1-way analysis of variance (Sokal and Rohlf, 1981). Therefore, results from all 6 sides of each monthly set of panels were combined for the analysis. The number of species had a normal distribution and was treated using parametric methods.

\section{RESULTS}

\section{Number of species}

Forty-nine species were observed, of which 22 were considered rare (i.e. $-5 \%$ occurrence on all panels). Thirteen species were sessile animals ( 2 rare), 22 were 
motile animals (15 rare) and 14 were algae (5 rare). Rare species were never represented by more than 4 individuals per series of panels. The number of species collected in each of the 3 series - summer 1978, winter 1979 and summer 1979 - are shown in Fig. 2.

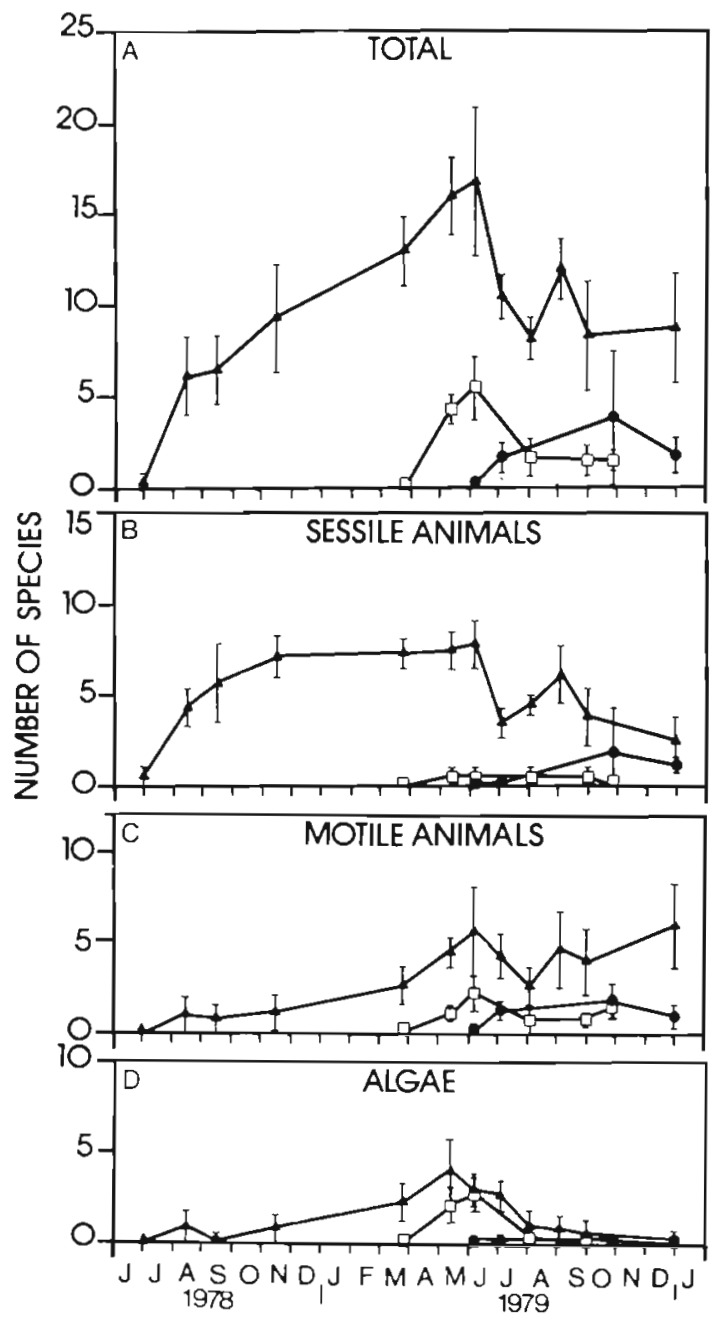

Fig. 2. Colonization on the series of panels immersed in June 1978 (4), in November $1978(\square)$ and in May $1979(\bullet)$. (A) Total number of species; (B) number of sessile animal species; (C) number of motile animal species; (D) number of algal species. Bars: \pm 1 standard deviation about mean

Panels immersed in summer 1978. Two successive trends are observed for the total number of species on panels immersed in the summer of 1978 (Fig. 2a). From June 1978 to June 1979, there was a gradual increase in the number of species. Then following an abrupt reduction from May to June 1979, the number of species remained relatively constant.

Sessile animals were the main colonizers during the first summer (Jun-Sept 1978; Fig. 2b). Except for the March to June 1979 period, the sessile species curve follows the same trends as the total species curve.
There was an overall increase of the number of motile species over the entire sampling period (Fig. 2c). The number of algal species peaked in June 1979, after which it decreased regularly until the end of the observation period (Fig. 2d). The total number of rare species at each date ranged from 0 to 6 . The number was highest during the 3 last periods (Sept 1979 to Jan 1980). This peak was due to the presence of motile species.

Panels immersed in winter 1979. These panels contained representatives of few species; they revealed the same pattern of change in number of species as the panels immersed in summer 1979. The spring peak was due to the settlement of algae and motile animal species, most of which disappeared in the summer.

Panels immersed in summer 1979. The panels immersed in the second summer collected fewer species than those placed in the summer of 1978. These panels were equally colonized by sessile and motile animals, and macroscopic algae were almost nonexistent (Fig. 2b, c, d).

\section{Colonization and decolonization rates}

The monthly colonization and decolonization rates (including emigration and mortality) were calculated from the number of new and departed species at each sampling date on panels immersed in the summer of 1978. The rates varied seasonally (Fig. 3). They were high in summer (Jun, Jul, Aug), and low in autumn and winter (Oct to May). Since the calculation of these rates is dependent on the length of the period between the

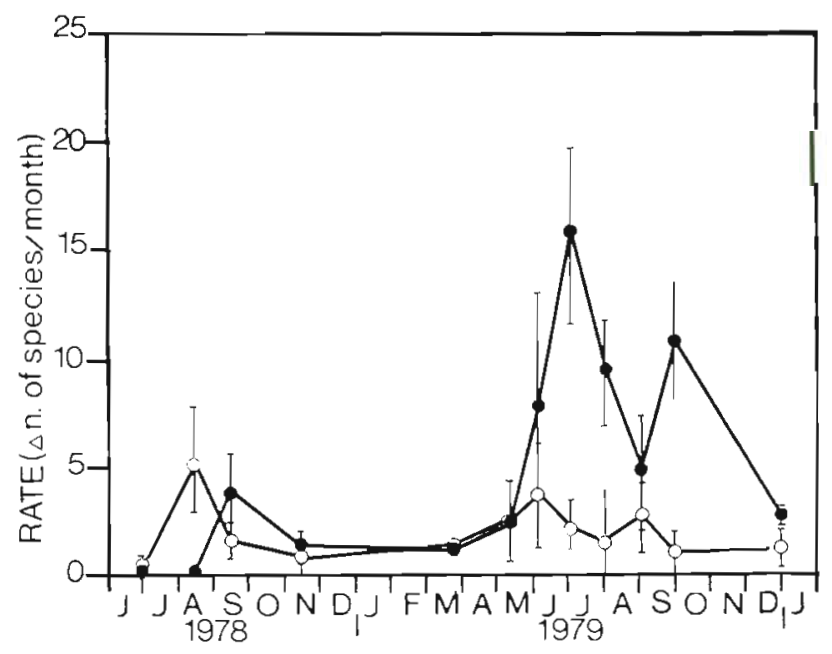

Fig. 3. Monthly colonization (O) and decolonization ( $\bullet$ ) rates calculated as

number of new or lost species at time $t$ $\left(t-t_{-1}\right)$ 
collection of 2 samples (Simberloff and Wilson, 1969; Schoener, 1978), the level of the March 1979 rates might be artificially low. However, the decolonization rates of November 1978 and May 1979 were almost as low as those observed in March, indicating that the lower winter rates are not sampling artifacts. The higher decolonization rates in 1979 were caused by the simultaneous disappearance of sessile animal species and increase in occurrence of rare motile species. The immigration rate was approximately equal to the extinction rate throughout winter and spring.

To test whether all 3 groups of species (sessile animals, motile animals, algae) had the same patterns of colonization and of decolonization, Pearson's correlation coefficients were calculated between pairs of all the possible combinations of these 6 variables (Sokal and Rohlf, 1981). The arrival of new species was not significantly correlated between the three groups, suggesting that they settled independently. However, species decolonizations in the 3 groups were all significantly correlated $(\mathrm{n}=72, \mathrm{r}=0.26-0.45, \mathrm{p}=0.01$ ).

\section{Abundance}

Total number of organisms. The variations in total number of individuals (sessile and motile) for the 3 series of panels are shown in Fig. 4. On the panels

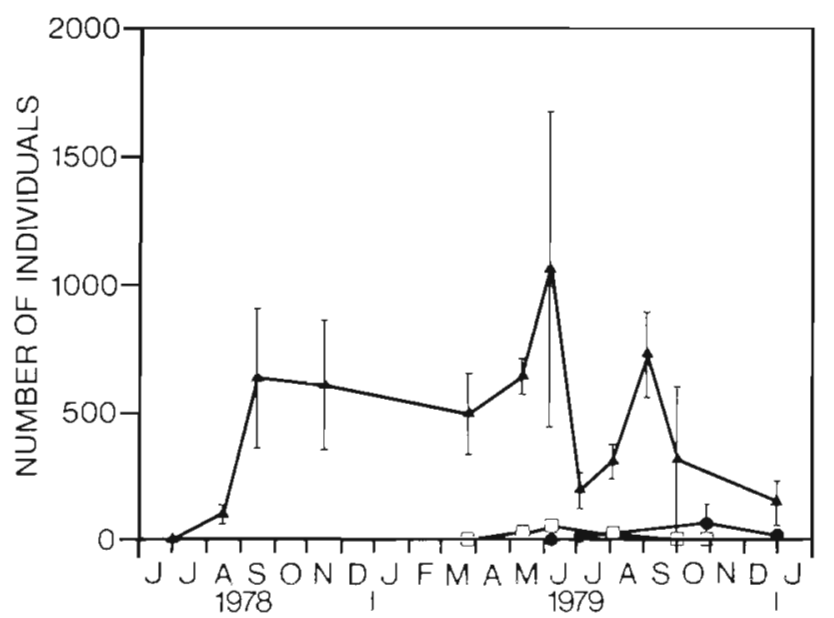

Fig. 4. Change of total number of individuals (sessile and motile animals, algae), for panels immersed in June 1978 (4), in November 1978 ( $\square$ ), and in May $1979(\bullet)$. Bars: \pm 1 standard deviation about the mean

immersed in June 1978, the total number increased rapidly to a plateau until the next summer. After May 1979, large variations were observed, and on the whole, values were lower than in the previous year. By contrast, the panels immersed in November 1978 and in May 1979 attracted very few organisms. Both series

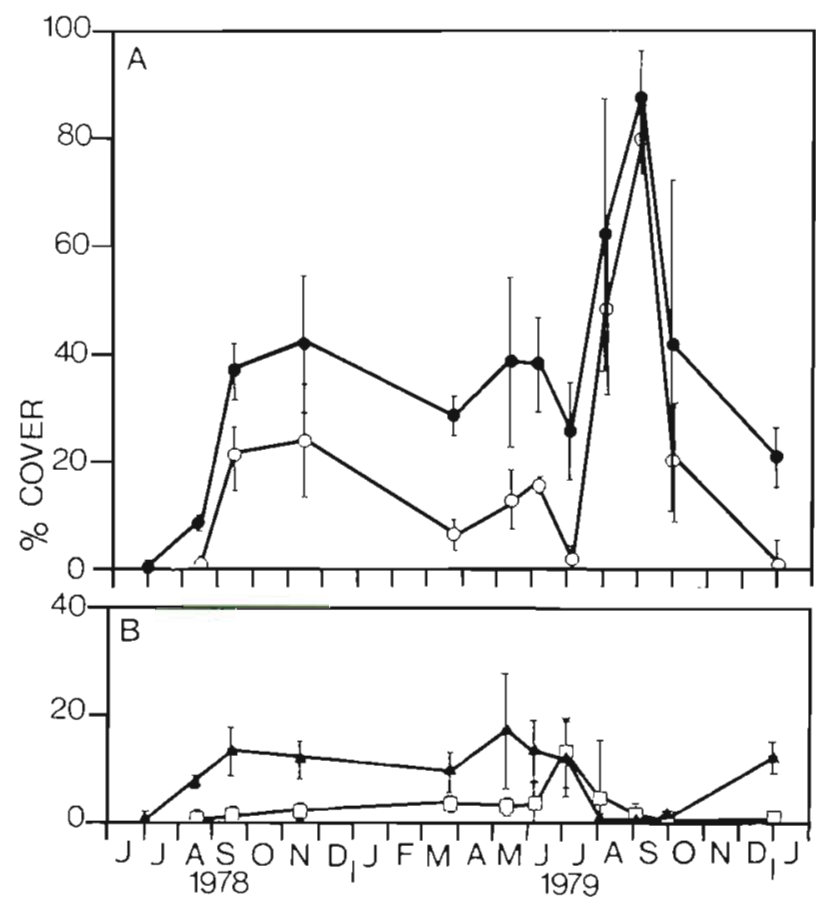

Fig. 5. Changes in abundance (\% cover) of sessile organisms on panels immersed in June 1978. (A) Total abundance (•), Balanus crenatus (O); $(B)$ Obelia longissima (A); all other species, including animals and algae ( $\square$ ). Bars: \pm 1 standard deviation about the mean

peaked at about 50 to 70 individuals per panel side following a period of immersion of 7 and 5 mo respectively.

The sessile fraction of the community (animals and algae) was dominated throughout by Balanus crenatus and/or Obelia longissima. Only once (Jul 1979) did these 2 species account for less than $86 \%$ of the total area covered by the organisms.

Two Balanus crenatus settlement peaks were observed during the study (Fig. 5a and 6a). Both occurred in September. The highest peak, in 1978, caused only a moderate rise in percent cover because of the small size of spat ( 1 to $2 \mathrm{~mm}$ ). The winter mortality of $B$. crenatus associated with the destruction of the hummocks explains the decrease in abundance observed in March 1979. After July, the assemblage was dominated by a relatively small number of barnacles, their large size (1.0 to $2.2 \mathrm{~cm}$ dia) accounting for their high percent cover. The recruitment of $B$. crenatus in 1979 was lower than in 1978 , and 34 to $72 \%$ of the spat settled on old barnacles or bases remaining after the barnacles were detached. It was inmediately followed by a high mortality of the spat and older barnacles.

The cover of Obelia longissima stolons remained relatively constant, between 10 and $20 \%$ until July (Fig. 5b). This species then suffered high mortality and recovered only after October 1979 when a new settle- 
ment was observed. It occurred later (Oct instead of Jun in 1978), and was also reduced compared to 1978, when Obelia invaded all the available space around the sampling site.

Mytilus edulis settled more or less continuously throughout the study (Fig. 6b). They were first observed mostly on hydrozoan upright branches, as frequently observed (Seed, 1976). After November 1978, they were found aggregated along stolons and the margins of barnacles. They appeared to be associated with the presence of 'mud' that formed a thin layer over the whole assemblage of organisms. A new mussel settlement was observed at the end of the summer of 1979, but most settled individuals disappeared in October. The majority of these mussels were attached directly to the older barnacles remaining on the panels.

The motile amphipod Podoceropsis nitida was also considered part of the sessile group, because of its tube building habit. Their membranous tubes were found on all types of substrata (panel surfaces, algae, hydroids, operculae and parietes of barnacles). They were abundant from May to August 1979, present during the autumn, and abundant again in December.

The polychaete Autolytus prismaticus (Fig. 6b) was the only species never found on bare substratum; it usually built its membranous tube along Obelia longissima stolons or at the margins of barnacles. Sediment always accumulated in the vicinity of the tubes. The first $A$. prismaticus were observed in March, and none remained after the disruption of the barnacle cover in June 1979.

The tubicolous polychaete Spirorbis borealis and 3 species of encrusting ectoprocts (Hyppothoa hyalina,
Tegella unicornis, Lichenopora hispida) were also common but never reached high numbers (max. of 20 $S$. borealis and of $28 \mathrm{H}$. hyalina in May 1979). After June 1979, $S$. borealis disappeared completely from the panels and the ectoprocts were present only occassionally.

The algae, in spring 1979 (Mar to Jun panels) reached their highest level of abundance (Fig. 6c). On the panels immersed in summer 1978, almost all algae were attached to the hydroids ( $\mathrm{X}=97 \%$, $\mathrm{STD}=0.8 \%$ ). During the same period (Mar to Jun 1979), on the panels immersed during the winter which had no Obelia longissima, they were all directly attached to the bare substratum. In both series the algae were mainly filamentous and foliose red algae and young Laminariaceae. Two outbreaks of solitary and filamentous diatoms occurred in May and June 1979, smothering the plates and their organisms.

On the March, May and June 1979 panels, the assemblages reached their greatest structural complexity. Almost all interstices between barnacles (then usually in hummocks), and Obeliga longissima stolons and branches, were occupied by Podoceropsis nitida and Autolytus prismaticus tubes, small Mytilus edulis, Spirorbis borealis and bryozoans.

Motile organisms. Of all the motile species recorded, amphipods were by far the most common and abundant. They varied from 3 to 109 for Podoceropsis nitida, 10 to 57 for Metopa alderi, 1 to 23 for pontogeneia inermis, and 2 to 178 for Caprella linearis. However, their high mobility may have biased their quantitative evaluation. Of the remaining 20 motile species (predators or grazers), only 4 were relatively common. Two peaks of abundance in spring and summer 1979
Fig. 6. Number of individuals on panels immersed in June 1978. (A) Balanus crenatus; (B) Mytilus edulis $(\bullet)$, Autolytus prismaticus (O); (C) all algae (arrows: presence of diatoms in unusual abundance); (D) motile animals excluding amphipods. Vertical scales of $(A)$ and $(B)$ differ from those of (C) and (D)
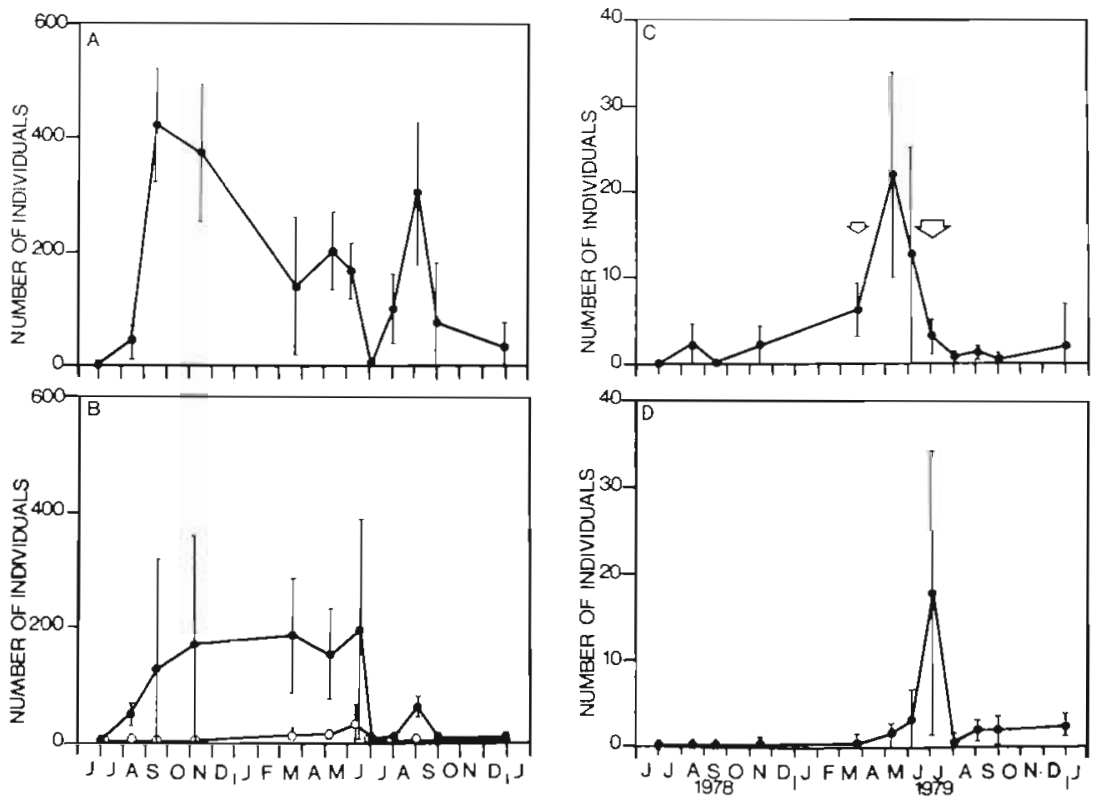
(Fig. 6d) were mainly due to 3 species of nudibranchs. In autumn 1979, a plateau of 10 to 14 individuals per panel was observed, with almost as many taxa represented as individuals: gastropods, platyhelminthes, ophiuroids, acarians, etc.

\section{Effect of dominant species on other sessile organisms}

Balanus crenatus and Obeliga longissima were used extensively as substrata by the sessile organisms. To know whether $B$. crenatus affected the settlement of other sessile organisms, densities of sessile organisms on bare substratum and on $B$. crenatus were calculated for each panel of the series immersed in summer 1978. A Wilcoxon matched-pairs signed-rank test indicates a significantly higher abundance of animals on barnacles than on bare substratum $(\mathrm{Z}=3.88$, 1-tailed $\mathrm{p}$ $>0.001)$. However, densities on both substrata followed the same trend (Spearman's $r=.39, p=.003$ ) throughout the study. Changes in density of organisms attached to $B$. crenatus were not correlated with changes in percent cover of the latter $(r=.03$, $\mathrm{p}=.413)$. A visual comparison of their 2 curves

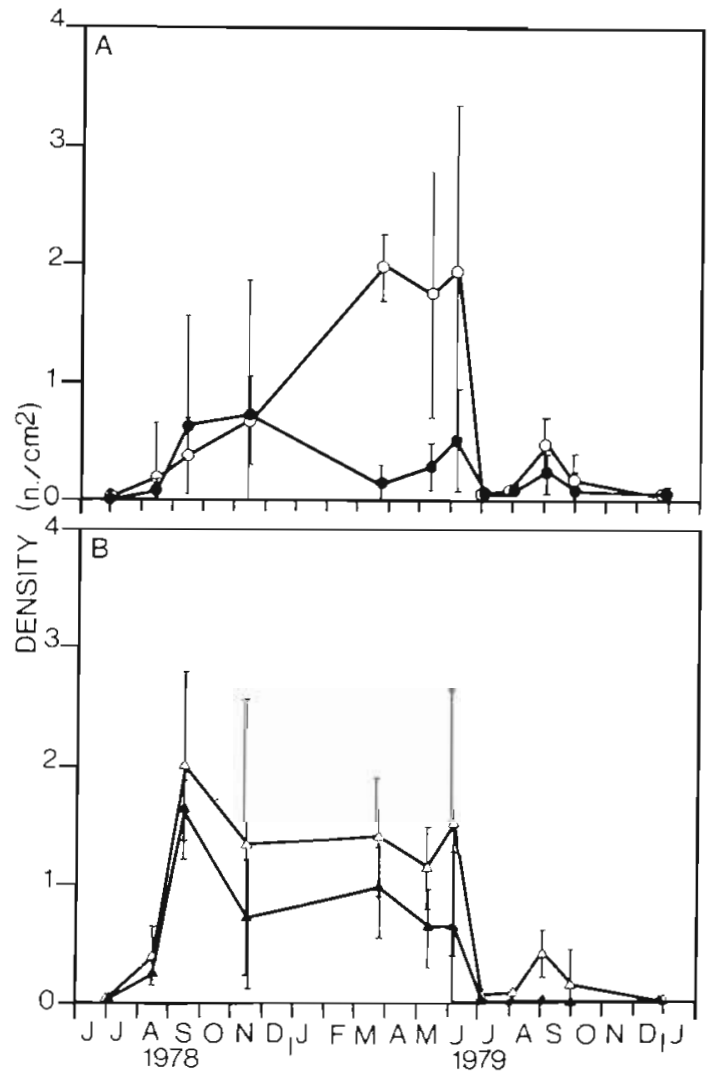

Fig. 7. Density of sessile organisms (animals and algae). (A) Epibionts on Balanus crenatus (O), and on primary substratum $(\bullet)$; (B) epibionts on Obelia longissima ( $\mathbf{A})$, and total density $(\triangle)$ Bars: \pm 1 standard deviation about the mean

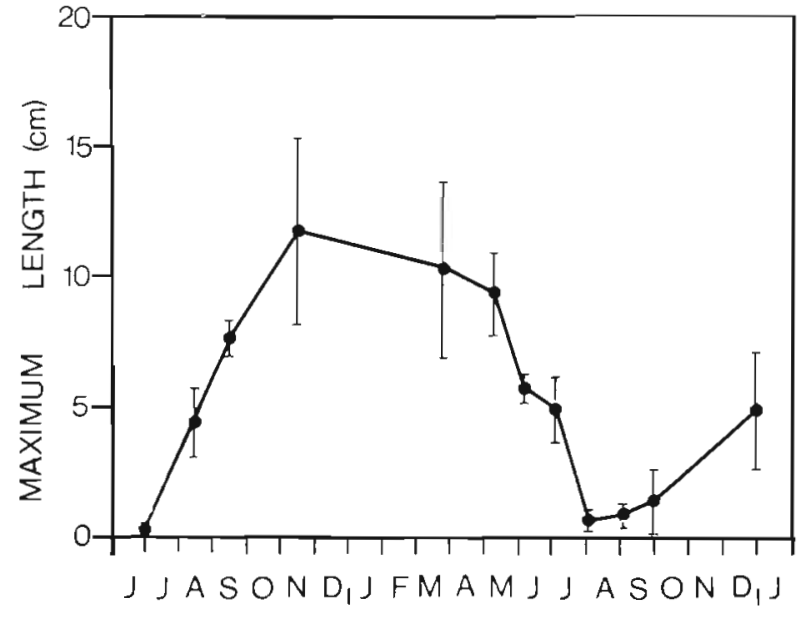

Fig. 8. Obelia longissima. Maximum length of stems. Bars: \pm 1 standard deviation about the mean

(Fig. 5a for percent cover of barnacles, Fig. 7a for density of sessile organisms on $B$. crenatus) shows that they do not reach strong peaks at the same periods.

The upright branches of Obelia longissima were also used as substratum for various colonizers (Fig. $7 \mathrm{~b}$ ) (Mytilus edulis, 62 to $100 \%$ of all individuals, algae, Autolytus sp., Spirorbis sp., in order of importance). Algae were considered here as one group, because of their similar colonizing pattern. On the panels immersed in winter and summer 1979, no sessile macro-organisms were ever found on hydrozoans.

A direct measure of the degree of development of the upright part of Obelia colonies (as biomass or volume) was difficult to obtain because the stems were at times abundantly colonized by living organisms and amphipod tubes. Instead, the maximum length of these stems has been subjectively chosen as an index of density of the canopy, as these two features were always observed to be closely related. Maximum length followed a yearly cycle (Fig. 8). It was correlated with percent cover of the stoloniferous parts (Fig. 5b) $(r=.81, p=.001)$, as well as with the number of live organisms it supported (Fig. 7b) $(\mathrm{r}=.80, \mathrm{p}=.001)$.

\section{DISCUSSION}

\section{Seasonality}

Invasion of newly exposed substrata varied seasonally. This marked seasonality is well illustrated when the panels immersed in the summer $(1978,1979)$ are compared with those of the winter 1979. If we consider solely the period of settlement of algae, motile and sessile animals, the seasonal patterns in the commun- 
ity were repeated during the 2 yr of observation. Summer panels of 1978 and 1979 were quickly colonized, mostly by sessile animals, and after 3 mo there was an average of 3 species per side. Panels immersed in winter showed no colonization after $3 \mathrm{mo}$. Their first colonizers were usually algal species in spring. Despite a lower level of colonization, the panels immersed in summer 1979 showed the same trend as those observed on the panels immersed in the previous summer: there was no time lag between time of immersion and arrival of the first colonizers, and sessile animals dominated the panels.

A seasonal trend also occurred in both colonization and decolonization rates observed on the panels immersed in summer 1978. High and variable rates were found in summer, lower and steadier rates in winter. Marked seasonal settlement patterns have frequently been reported in subtidal communities, particularly at high latitudes (Dean, 1977; Osman, 1977. 78; Schoener et al., 1978; Arntz and Rumohr, 1982).

Intensity of settlement in 1978 and 1979 can be compared in the series immersed in the 2 summers. Colonization in 1978 was greater and more rapid (Fig. 2a, 4). Thus, although the annual settlement pattern of the different groups of species appears predictable, the number of species and individuals are extremely variable from year to year.

Timing of settiement and its intensity are not equally predictable because they are controlled by different factors. In benthic organisms, especially those with planktonic stages, gonad maturation and spawning or release of spores is often synchronized with cyclical environmental events, such as temperature changes (Seed, 1976; Clark, 1979), or phytoplankton blooms (Himmelman, 1981). It has been postulated that these recurrent factors are cues indicating the presence of good conditions for these species (Thorson, 1946; Wilbur et al., 1974). Algae and sessile animals, for instance, tend to colonize at different times (algae in spring, animals in summer), presumably because they have different requirements for survival. This trend is shown by the absence of correlation between the new species groups. The number of organisms, on the other hand, depends on the reproductive success of the adults and on the survivorship of larvae or of spores. Since pressures on the populations are likely to be different from one reproductive cycle to the next (usually 1 yr in temperature climates), abundances are less predictable. Yearly fluctuations are apparent in Obelia longissima. In 1978, this species had a very successful settlement but a very poor one in 1979 and in 1980 . Such variations have been reported in several other studies (Kain, 1975; Sutherland and Karlson, 1977; Davies and Van Blaricom, 1978; Arntz and Rumohr, 1982).

\section{Species equilibrium}

The colonization curve of panels immersed in the summer of 1978 first has a positive slope, and then levels off (Fig. 2a). This has often been interpreted as a gradual increase in the number of species up to a plateau of equilibrium (e.g. Simberloff and Wilson, 1969; Schoener, 1979; Sutherland and Karlson, 1977; Osman, 1978). In this study, the colonization curve levels off around July 1979. Thus, following this interpretation, the equilibrium number of species would be of about eight species per panel side.

The equilibrium number of species is defined as the number at which colonization and decolonization rates are equal and at a low level (MacArthur and Wilson, 1967). Calculation of the difference between colonization and decolonization rates is then a more rigorous method for testing the occurrence of species equilibria (Schoener, 1978). Using this method, an equilibrium point was apparently reached between March and May 1979 (Fig. 3). It occurred when the species number reached its highest level. The large differences between the 2 rates after May indicate that the assemblages were then in a state of non-equilibrium, rather than at the plateau first hypothesized. To this period of wide differences between the 2 rates corresponds a disintegration of the community, as seen by the reduction in density and species abundances of sessile organisms during summer 1979. So, communities under important structural changes could have an apparent equilibrium plateau, i.e. a constant number of species. The plateau of about 8 species observed after June 1979 was the result of the replacement of numerically dominant sessile species by mostly rare motile species having a higher rate of disappearance.

\section{Interactions}

Our observation of some biological interactions during community development enables us to determine some factors responsible for the changes observed. That settled organisms enhance the settlement of new species is strongly supported by (1) the contrast between the significant increase in species number in winter 1979 on panels immersed in summer 1978 and the absence of colonization during the same period on panels immersed in winter; (2) the contrast between the increase in number of individuals in June and September 1979 on panels immersed in summer 1978 (Fig. 4) and the constant low numbers in the two other series of panels; (3) the higher density of sessile organisms on Balanus crenatus than on the bare panels. The positive effect of biogenic structures which allow new 
species and more individuals to find refuges in this complex environment has often been described (Dean, 1977; Osman, 1977; Vance, 1978; Woodin, 1978; Goren, 1979; Russ, 1980).

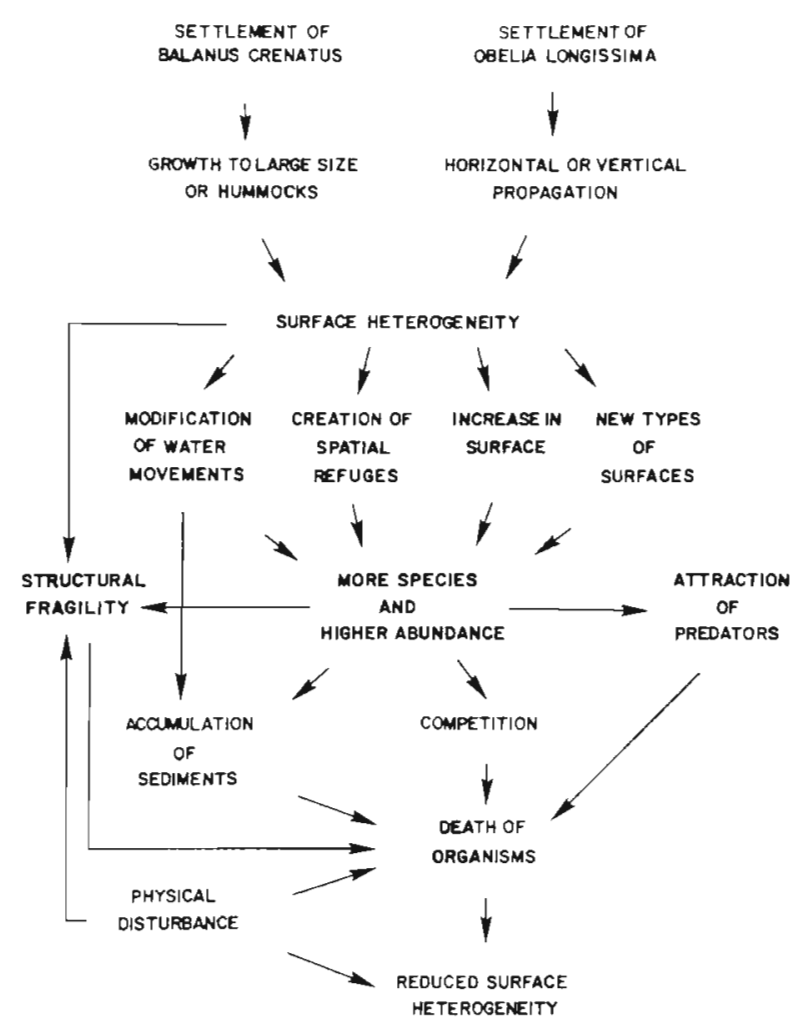

Fig. 9. Schematic representation of events on panels immersed in June 1978. Arrows: observed or possible causal relations

Fig. 9 summarizes schematically the events observed in our 1978 series and their possible effects on the community. The 2 dominant species create a complex 3-dimensional topography. Balanus crenatus can grow to a large size and form hummocks, and Obelia longissima propagates vegetatively over the surface by stolons and above it by upright branches. In modifying the surface of the panels, they change their attractiveness to new organisms in several ways.

These 2 species increase the surface available for settlement. This change may be significant, since space for attachment is a scarce resource for epibenthic organisms (Dayton, 1971; Connell, 1972). The formation of hummocks by barnacles can more than double the original area of a panel (Dahl, 1973). However, since organisms on Balanus crenatus were up to 10 times more numerous than on the panels (Fig. 7a), other mechanisms must also be responsible for this attractiveness.

Barnacle shells and Obelia longissima branches modify the texture of the substratum. Since, in many species, settling larvae can detect differences in surface quality and exhibit preferences (Kright-Jones et al., 1971; Seed, 1976; Hudon et al., 1983), such a change will probably favour the settlement of organisms which may not be found on a flat substratum. For instance, the polychaete Autolytus prismaticus was always found along irregularities on the panels and on natural surfaces. Mytilus edulis larvae will settle preferentially on filamentous substrata (Bayne, 1964; Seed, 1976; Standing, 1976). In June 1979, the panels immersed a year earlier were colonized by mussels, two-thirds of which were attached to O. longissima. None were found on the panels immersed in winter 1979 which had no $O$. longissima. In spring 1979, algae heavily colonized hydroids on panels immersed summer 1978, while they attached directly to the panels immersed in winter which were devoid of $O$. longissima colonies.

Balanus crenatus and Obelia longissima also probably create spatial refuges for settling larvae and adults of many species. Refuges have been shown decisive for the survival of organisms against predators (Vance, 1978; Hawkins, 1981) and physical disturbances (Dayton, 1971; Kohn and Leviten, 1976). However, the present experiments were not designed specifically to distinguish the effect of refuges from those of area increase and of change in texture on larval settlement.

Biotic heterogeneity includes numerous effects, but they are globally shown as increases of richness and abundance of the assemblage (Fig. 2 and 4). This is in accordance with Odum's (1969) prediction of an increase in both structural complexity and diversity. It has been argued that this complexity will increase the resistance and resilience of the community to disturbances. The classical concept of succession consists of a progressive replacement of species where the early colonists disappear, giving way to newer species. However, in this epibenthic assemblage the later colonists depend on the persistence of the earlier colonists for their own survival. Any factor producing mortality in Balanus crenatus and Obelia Iongissima will consequently destabilize the community and lead to a poorer one.

The new topography also changes the pattern of current flow around the panels, and probably causes the observed accumulation of sediments within and under the Obelia longissima canopy (Neushul et al., 1976; Fonseca et al., 1982). Smothering of barnacle spat by sediments and reduction of food supply due to lowered flow could play a role in their heavy mortality following settlement. Similarly, the bulk of epizoics within the $O$. longissima canopy increases interferences with water movements. At the same time they increase the chances that hydroid branches be torn off. 
Dense assemblages in an otherwise poor environment will inevitably attract predators. This can be seen in the gradual increase in the number of motile species on the series of summer 1978 (Fig. 2C), and by their peak abundance in July 1979 (Fig. 6d). This peak was caused by 3 species of nudibranchs, known as predators of hydrozoans (Hyman, 1967). Although maximal length of Obelia longissima branches follows a yearly cycle (Fig. 8), their sudden unhealthy appearance and the absence of hydranths in August and September 1979 are probably indicative of predation. Dense settlement resulting in intraspecific competition (evidenced by the presence of hummocks of Balanus crenatus) and eventually structural fragility in the hummocks, are also source of mortality (Barnes and Powell, 1950; Connell, 1961).

The impact of these various processes on the whole assemblage is radical. Two peaks in the species decolonization rate, in July and in October 1979, are synchronous with, respectively, the elimination of upright stalks of Obelia longissima from the panels, and the heavy mortality of Balanus crenatus. The abundances of the other sessile species undergo a severe drop at the same moments. The survival of associated fauna and flora is directly linked to the persistence of the physical structure provided by the 2 dominants. Both $B$. crenatus and $O$. longissima enhance short-term, small-scale maintenance of the sessile assemblages but later on will destabilize and impoverish the same assemblages by their rapid disappearance. The role of these species is comparable to the functional role of Styela plicata species in Sutherland's (1978) study which similarly keeps the assemblage in the same state for a length of time, then disrupts it by sloughing off. However, the stabilization effect is caused by different mechanisms in the 2 cases: Styela species resists invasion by other species, whereas $O$. longissima and $B$. crenatus attract settling organisms.

Balanus crenatus and Obelia longissima reproduce seasonally by numerous small larvae capable of invading available space and of monopolizing it. Their development is rapid, and they may undergo drastic changes in their densities. By these characteristics, they are comparable to the 'early successional' species of the terrestrial plant systems (Odum, 1969; Drury and Nisbet, 1973). These terrestrial species modify the environment not only by their presence, but also by changing many of its physical features, some transformations remaining even after the death of the individuals and the disappearance of the species. These changes caused by the early colonists often tend to inhibit recolonization by their own species (Clements and Shelford, 1939; Keever, 1950). In our epifaunal community, the biogenic transformations of the environment caused by $O$. longissima simply disappear with the hydroid. Consequently, these tranformations have no effect on the next recruitment of $O$. longissima. In contrast, the presence of barnacle bases that persist after the death of the individuals enhances the settlement of barnacle larvae (Knight-Jones, 1953). These neutral and positive effects differ from the above situation in the plant systems. It suggests that $O$. longissima and $B$. crenatus include some form of persistence in their life-history strategies. Moreover, since they both attract a higher density of epibionts than the bare substratum, they will cause massive mortality of these organisms as the 2 species break or slough off the substratum. They therefore free the substratum of its non-dominant species.

Balanus crenatus and Obelia longissima are dominant species, which implies that over a number of generations they have successfully maintained their numbers. It is suggested here that they have done so by securing available substrata using 3 strategies: (1) dense and early colonization and/or a rapid growth; (2) higher attractiveness than a flat substratum to settling organisms, causing the elimination of other species at the time of their own disappearance; (3) positive or neutral attractiveness to the settling larvae of their own species, enhancing the rapid reestablishment of their local population.

Acknowledgements. We thank Ted Hutchinson for precious collaboration in the field and during preparation of the manuscript. We are also grateful to Guy Martel, Monique Bousquet, Dr John Himmelman, Dr. Christiane Hudon und Dr R. A. Myers who have helped at various stages of the study. This study was supported by grants from NSERC to E. B. (A0511), the Quebec Department of Education to GIROQ and Approvisionnement et Services Canada. This work was carried out while the senior author (S.B.) held a FCAC scholarship

\section{LITERATURE CITED}

Arntz, W. E., Rumohr, H. (1982). An experimental study of macrobenthic colonization and succession, and the importance of seasonal variation in temperate latitude. J. exp. mar. Biol. Ecol. 64: 17-45

Bames, H., Powell, H. T. (1950). The development, general morphology and subsequent elimination of barnacle populations, Balanus crenatus and $B$. balanoides, after a heavy initial settlement. J. Anim. Ecol. 19: 175-179

Bayne, B. (1964). Primary and secondary settlement in Mytilus edulis L. (Mollusca). J. Anim. Ecol. 33: 513-523

Brock, R. E. (1979). An experimental study on the effects of grazing by parrotfishes and the role of refuges in benthic community structure. Mar. Biol. 51: 381-388

Clark, K. B. (1979). Environmental determination in Polychaetes. In: Stancyk, S. E. (ed.) Reproductive ecology of marine reproductive ecology of marine invertebrates. The Belle Baruch Library in Marine Science 9: 107-121

Clements, F. E. (1916). Plant succession. Carnegie Inst. Wash. Publ. 242

Clements, F. E., Shelford, V. E. (1939). Bio-ecology. John Wiley, New York 
Connell, J. H. (1961). The influence of competition, predation by Thais lapillus, and other factors on natural populations of the barnacle Balanus balanoides. Ecol. Monogr. 31: 61-104

Connell, J. H. (1972). Community interactions on marine rocky intertidal shores. Ann. Rev. Ecol. Syst. 31: 169-192

Connell, J. H., Slatyer, R. O. (1977). Mechanisms of succession in natural communities and their role in community stability and organization. Am. Nat. 111: 1119-1144

Dahl, A. L. (1973). Surface area in ecological analysis: quantification of benthic coral-reef algae. Mar. Biol. 23: $239-249$

Davies, N., VanBlaricom, G. R. (1978). Spatial and temporal heterogeneity in a sand bottom epifaunal community of invertebrates in shallow water. Limnol. Oceanogr. 23: 417-427

Dayton, P. K. (1971). Competition, disturbance and community organization: the provision and subsequent utilisation of space in a rocky intertidal community. Ecol. Monogr. 41: 351-389

Dayton, P. K. (1975). Experimental evaluation of ecological dominance in a rocky intertidal algal community. Ecol. Monogr. 45: 137-159

Dean, T. A. (1977). Succession in a marine fouling community: changes in community structure and mechanisms of development. Ph. D. Dissertation, University of Delaware, Newark, Delaware

Drury, W. H., Nisbet, I. C. T. (1973). Succession. J. Arnold Arboretum Harvard Univ. 54: 331-368

Elliot, J. M. (1971). Some methods for the statistical analysis of samples of benthic invertebrates. Freshwat. Biol. Ass., Scient. Publ. 25: 1-148

El-Sahb, M. I. (1976). Surface circulation pattem in the Gulf of St. Lawrence. J. Fish. Res. Bd Can. 33: 124-138

Fonseca, M. S., Fisher, J. S., Zieman, J. C., Thayer, G. W. (1982). Influence of the seagrass, Zostera marina, L. on current flow. Estuar. coast. Shelf Sci. 15: 351-364

Goren, M. (1979). Succession of benthic community on artificial substratum at Elat (Red Sea). J. exp. mar. Biol. Ecol. 38: $19-40$

Grime, J. P. (1977). Evidence for the existence of three primary strategies in plants and its relevance to ecological and evolutionary theory. Am. Nat. 111: 1169-1194

Hawkins, J. S. (1981). The influence of season and barnacles on the algal colonization of Patella vulgata exclusion areas. J. mar. biol. Ass. U. K. 61: 1-15

Himmelman, J. H. (1981). Synchronization of spawning in marine invertebrates by phytoplankton. In: Clark, W. H., Jr., Adams, T. S. (ed.) Advances in invertebrates reproduction. Elsevier, Amsterdam, p. 3-19

Hudon, C., Bourget, E., Legendre, P. (1983). An integrated study of the factors influencing the choice of the settling site of Balanus crenatus cyprid larvae. Can. J. Fish. aquat. Sci. 40: 1186-1194

Hyman, L. H. (1967). The invertebrates: Moliusca I. Vol. 6, 1st ed. McGraw-Hill, New York

Jackson, J. B. C. (1977). Competition on marine hard substrata: the adaptative significance of solitary and colonial strategies. Am. Nat. 111: 743-767

Kain, J. M. (1975). Algal recolonization of some cleared subtidal areas. J. Ecol. 63: 739-765

Karlson, R. H., Cariolou, M. A. (1982): Hermit crab shell colonization by Crepidulla convexa Say. J. exp. mar. Biol. Ecol. 65: 1-10

Keever, C. (1950). Causes of succession on old fields of the Piedmont, North Carolina. Ecol. Monogr. 20: 229-250

Knight-Jones, E. W. (1953). Laboratory experiments on gre- gariousness during settlement in Balanus Balanoides and other barnacles. J. exp. Biol. 30: 585-598

Knight-Jones, E. W., Bailey, J. H., Isaac, M. J. (1971). Choice of algae by larvae of spirorbis, particularly of Spirorbis spirorbis. In: Crisp, D. J. (ed.) 4 th European Marine Biology Symposium, Bangor. Cambridge University Press, London, p. 89-105

Kohn, A. J., Leviten, P. J. (1976). Effects of habitat complexity on population density and species richness in tropical intertidal predatory gastropod assemblages. Oecologia 25: $199-210$

MacArthur, R. H., Wilson, E. O. (1967). The theory of island biogeography. Princeton University Press, New Jersey

Menge, B. A. (1976). Organization of the New England rocky intertidal community: role of predation, competition, and environmental heterogeneity. Ecol. Monogr. 46: 355-393

Neushul, M., Foster, M. S., Coon, D. A., Woessner, J. W., Harger, B. W. W. (1976). An in situ study of recruitment, growth and survival of subtidal marine algae: techniques and preliminary results. J. Phycol. 12: 397-408

Odum, E. P. (1969). The strategy of ecosystem development. Science, N. Y. 164: 262-270

Osman, R. W. (1977). The establishment and development of a marine epifaunal community. Ecol. Monogr. 47: 37-63

Osman, R. W. (1978). The influence of seasonality and stability on the species equilibrium. Ecology 59: 383-399

Paine, R. T. (1974). Intertidal community structure. Experimental study on the relationship between a dominant competitor and its principal predator. Oecologia 15: 93-120

Paine, R. T. (1980). Food webs: linkage, interaction strength and community infrastructure. J. Anim. Ecol. 49: 667-685

Pianka, E. R. (1970). On r- and K-selection. Am. Nat. 104: $592-597$

Russ, G. R. (1980). Effects of predation by fishes, competition and structural complexity of the substratum on the establishment of a marine epifaunal community. J. exp. mar. Biol. Ecol. 42: 55-70

Schoener, A. (1979). Experimental zoogeography: colonization of marine mini-islands. Am. Nat. 108: 715-737

Schoener, A., Long, E. R., DePalma, J. R. (1978). Geographic variation in artificial island colonization curves. Ecology 59: $367-382$

Seed, R. (1976). Ecology, In: Bayne, B. L. (ed.) Marine mussels: their ecology and physiology. Cambridge University Press, Cambridge, p. 13-65

Simberloff, D. S., Wilson, E. O. (1969). Experimental zoogeography of islands: the colonization of empty islands. Ecology 50: $278-295$

Sokal, R. R., Rohlf, F. J. (1981). Biometry, 2nd ed. Freeman and Cie., San Francisco

Sousa, W. P. (1879). Disturbance in marine intertidal boulder fields: the non-equilibrium maintenance of species diversity. Ecology 60: 1225-1239

Sousa, W. P. (1980). The response of a community to disturbances: the importance of successional age and species's lite histories. Oecologia 45: 72-81

Standing, J. D. (1976). Fouling community structure: effects of the hydroid, Obelia dichotoma, and larval recruitment. In: Mackie, G. O. (ed.) Coelenterate ecology and behavior. Plenum Press, New York, London, p. 155-164

Sutherland, J. P. (1978). Functional role of Schizoporella and styela in the fouling community at Beaufort, North Carolina. Ecology 59: 257-264

Sutherland, J. P. (1981). The fouling community at Beaufort, North Carolina: a study in stability. Am. Nat. 118: 499-519

Sutherland, J. P., Karlson, R. H. (1977). Development and 
stability of the fouling community at Beaufort, North Carolina. Ecol. Monogr. 47: 425-446

Thorson, G. (1946). Reproduction and larval development of danish marine bottom invertebrates. Rietzel Forlag, Copenhagen

Vance, R. R. (1978). A mutualistic interaction between a sessile marine clam and its epibionts. Ecology 59:679-685
Wilbur, H. M., Tinkle, D. W., Collins, J. P. (1974). Evironmental certainty, trophic level, and resource availability in life history evolution. Am. Nat. 108: 805-817

Woodin, S. A. (1978). Refuges, disturbances, and community structure: a marine soft-bottom example. Ecology 59: $274-284$

This paper was submitted to the editor; it was accepted for printing on August 20, 1984 
